\title{
Conception of Social Justice in Eastern Indonesia within the Framework of the Republic of Indonesia
}

\author{
Anak Agung Gede Oka Wisnumurti ${ }^{1}$, I Putu Eka Mahardhika ${ }^{2}$, \\ I Gusti Agung Ayu Yuliartika Dewi ${ }^{3}$ \\ ${ }^{123}$ Lecturer in the Department of Administrative Sciences, Faculty of Social and Political Sciences, \\ Warmadewa University (email: ekaputu21@gmail.com)
}

\begin{abstract}
The country of Indonesia, which has abundant natural resources, with diverse tribes, races, religions, cultures, customs and thousands of islands that we often hear, the term jambrud equator is one of the many words that praise the richness of the archipelago. If you look at the data from the Central Statistics Agency (BPS) in 2018 about the human development index in Indonesia, the trend has experienced a good increase in 2018 at $71.39 \%$, with a trend in a period of almost a decade. from 2010-2018 experienced an average national growth of $0.88 \%$, the highest position was occupied by DKI Jakarta Province with the human development index figure at $80.47 \%$ with $0.51 \%$ growth from $2017-2018$ and the lowest was occupied by the Papua Province with 60, 64\% position with 1.64\% growth from 2017-2018. This research uses a conceptual approach. The conclusion in this study is that social justice in Indonesia which has a Pancasila ideology foundation provides a comprehensive concept of justice space, covering all sectors of national and state life that must be carried out by all citizens of the nation. In order to create comprehensive justice, the State must attend and have a scale of development priorities so that eastern Indonesia can have a quality of life that is equivalent to the population of Indonesia in the west.
\end{abstract}

\section{Keywords:}

social justice; Pancasila; Republic of Indonesia

\section{Introduction}

The narrative of Indonesia which is rich in natural resources, with a variety of tribes, religions, races, cultures, customs and thousands of islands we often hear, the term jambrud equator is one of the many words to praise the richness of the archipelago. As the era changes from the old order to the reform era, it becomes a historical record of unfinished development patterns in Indonesia. If citing a sentence from Bung Karno, the Proclamator, "Merdeka is Only 
a Bridge, Even though the Gold Bridge Across the Bridge is a Two-Way Break, One to the World is Equal to Sense, One to the World is Weeping and Weeping".

If you look at what is a phenomenon in the 2019 presidential election, the thickening of identity politics is inevitable or one-sided, blasphemous after blasphemy among the nation's children feels very thick and exhibited bravely on social media, expressions of hatred, hoax news and not admitted Pancasila movements without seeming to be without shame shows itself in the name of freedom of expression and opinion, of course this is only part of the portrait of a great nation's journey that we named the Indonesian Nation. With the emergence of these phenomena of course the next question is what is wrong with Indonesia? If we look back at how the enthusiasm and persistence of supporters of candidate pairs who contest the 2019 presidential election is certainly not excessive if we say the struggle for the highest leadership in this country is full of interests.

The current competing strengths and strategies seem to display polite and dynamic ethics of the archipelago. Strengthening religious identity is a legitimate tool used in a multiethnic country, religion, ethnicity and culture, the composition of the dominant population in Java automatically makes this power struggle increasingly centered on Java. When power is centralized in the land of Java automatically the physical and human development processes will be more concentrated in the land of Java, then how then development on other islands besides Java, where in Indonesia there are more than 17,000 islands that are also waiting for the realization of the fifth precepts of the Pancasila " Social justice for all the people of Indonesia".

If you look at the data from the Central Statistics Agency (BPS) in 2018 on the index of human development in Indonesia the trend has experienced a good increase in 2018 at a position of $71.39 \%$, with a trend in the period of almost a decade from 2010-2018 experiencing an average growth nationally at $0.88 \%$, the highest position occupied by DKI Jakarta with its human development index figure at $80.47 \%$ with a growth of $0.51 \%$ from $2017-2018$ and the lowest is occupied by Papua Province at $60.64 \%$ with a growth of 1.64\% from 2017-2018.

If at first glance we compare between Jakarta and Papua there is still a range of $10.75 \%$ of its human development index (HDI), and if we assume the average annual increase in Papua's HDI is in the same range of $1.64 \%$ annually then there is a range of distances 6.5 years 
to pursue Jakarta to be in the same position as Jakarta's record has not increased, but it is very unlikely that a province will survive and not make efforts to improve its Human Development Index and if Papua wants to pursue Jakarta in its human development index then hard work is needed from policy makers both at the National and in Papua to be able to catch up compared to other regions. In the perspective of a Unitary State frame, Indonesia does not only consist of western Indonesia, but there is still eastern Indonesia that needs serious attention and treatment so as to create equitable and equitable development in all fields in every region in Indonesia

In addition, when referring to the Preamble to the 1945 Constitution of the Republic of Indonesia, it is stated that the ideals of the Republic of Indonesia are, "protect all Indonesians and all of Indonesia's blood and to promote public welfare, enhance the life of the nation, and participate in implementing world order based on independence, eternal peace and social justice, "then guarding the government's move to create justice in eastern Indonesia is a necessity that must be met according to the mandate of the constitution in Indonesia. Based on the above background, the formulation of the problem in this study is What is the conception of justice for Eastern Indonesia in the Unitary State of the Republic of Indonesia?

\section{Research Methods}

Based on the problem under study, the library research method is used. The research method was carried out by examining existing library materials. The study uses a conceptual approach and a statute approach and a cultural approach.

\section{Literature Review}

\section{Concept of Justice}

Justice as part of social values has a very broad meaning, even at a point it can be contrary to the law as a social value system. The measure of justice reaches the ideal territory or is within the realm of ideals, because it talks about the issue of justice, it will speak to the deepening of the day of the nature of justice itself. Justice talks have a wide range, ranging from those that are ethical, philosophical, legal, to social justice. Many people think that being fair is easy, but certainly not so in practice in real life. The definition of justice itself is still plural and many experts put forward the definition of justice like Aristotle, arguing that justice is 
worthiness in human action, worthiness is interpreted as a midpoint between the two extremes of too much and too little. According to Plato, justice is projected on people. People who are fair, are people who control themselves and their feelings are controlled by reason. And according to Socrates, justice is projected on the Government, justice is created when every citizen has felt that the government has done its job properly.

\section{Social Justice}

As a large country, Indonesia has a nation ideology that we call Pancasila. In the 5th precepts of Pancasila, social justice for all Indonesian people is mentioned, which is a great goal for the Indonesian people. If citing a speech from the President of the Republic of Indonesia I Ir. Soekarno, in a public lecture on "Pancasila", which was held "The Pancasila League" at the State Palace mentioned the meaning of the word social justice "is a society or the nature of a just and prosperous society, happy for everyone, no humiliation, no oppression, no exploitation. Nothing - as I said in a public lecture a few months ago - exploitation de 1 'homme par l'homme". Observing Bung Karno's thoughts on the concept of social justice, it was hoped that it was clear that Seoekarno prioritized the value of justice and upheld the value of human rights in the concept of national and state life. The birth of the concept of social justice was certainly a reflection of Sukarno's experience in dealing with the colonial period at the time and it was very clear that the ideals of justice that were expected had to be felt from all, by all and for all.

Creating justice for all the people of Indonesia is certainly not easy, challenges for challenges will emerge with the changing times and changing positions of leadership in Indonesia. Starting with Freeport, the rights were given to foreigners during President Soeharto's reign which gave rise to long stories and various rejections and demands in his time and were only re-acquired in 2019 by President Joko Widodo

\section{Country}

The state is the most important concept in political science. The state has always been a study area because there are political and power struggles that are the easiest to see and recognize. The state is an integration of political power. It is the main organization of political power. The state is the agency (tool) of society which has the power to regulate human relations in society and curb the symptoms of power in society. 
Some world scientists put forward definitions of the concept of the State from different angles. Plato stated, "The state is an entity consisting of different parts that are complementary and interdependent and act together in pursuit of a common goal. Injury to anyone is a wound to all. If one of the members in this group is destitute or injured, the health of all members of the community is also affected. Our goal in upholding the state is not the imbalance of certain class happiness, but for the sake of happiness for all "Aristotle argues," The state is a family community and prosperous family collection for a perfect and adequate life "while Roger F. Soltou argues" The state is a tool (agency) or authority (authority) that regulates or controls joint issues on behalf of the community "On the other hand Harold J. Laski argues," The state is a society that is united because it has authority that is coercive and that is legally more noble than individuals or groups of people who live and work together to achieve their shared desires. Society is a country when life must be obeyed, and Max Waber gives the view, "The state is a human community that successfully monopolizes the use of legitimate physical force in certain areas".

If seen from a series of opinions of the experts it can be concluded that the State is the highest authority that has authority in regulating the livelihoods of people who live in a State.

\section{Social Justice for Eastern Indonesia}

The vast territory of the Unitary Republic of Indonesia from Sabang-Merauke which consists of more than 17,000 islands is a challenge in the development of this country, when viewed from the geographical conditions of Indonesia which is dominated by waters and the Merapi volcano group is certainly a separate note in the development process in Indonesia . On the other hand the diversity of cultures, customs, traditions to dynamic socio-political conditions of life is also a challenge that must be resolved in order to advance the State of Indonesia.

If seen in the period from independent Indonesia until before the reign of President Joko Widodo the development of this country is more concentrated in the western region of Indonesia precisely on the island of Java.

In terms of population composition, population density on Java ranks highest compared to other islands in Indonesia. The population distribution which is still concentrated in Java 
Island has resulted in more development on Java Island. This development imbalance also has implications for the welfare of its population. Based on data from the Badan Pusat Statistik (BPS) in March 2019, the highest population poverty rate was in Papua Province at $27.53 \%$, followed by West Papua Province 22.17\% and East Nusa Tenggara Province 21.09\%, this condition is very different when compared with the average the national average poverty rate in Indonesia is $9.41 \%$.

During the leadership of President Joko Widodo-Jusuf Kalla with the Nawa Cita program which was used as the driving force of development, there has been a shift in development to the eastern part of Indonesia, this is proven by the construction of the Palapa Ring concept. Palapa Ring is a telecommunications infrastructure project in the form of the construction of optical fiber throughout Indonesia along 36,000 kilometers. The project consists of seven small optical fiber circles (for Sumatra, Java, Kalimantan, Nusa Tenggara, Papua, Sulawesi and Maluku) and one backhaul to connect them all. The targets and strategies for building a national fiber optic network, which will reach 440 cities / regencies throughout Indonesia. The Palapa Ring project will integrate existing networks with new networks in eastern Indonesia (Palapa Ring-East). "Sovereignty / National Sovereignty" and "National Resilience" through the availability of integrated telecommunications infrastructure. Accelerating growth and equitable socio-economic development through the availability of integrated high-capacity telecommunications network infrastructure can provide high-quality, safe, and inexpensive quality internet and communications.

On the other hand, infrastructure development has also begun to be concentrated in eastern Indonesia, the construction of toll roads, airports and ports is evidence of the seriousness of the Government of Indonesia in developing its country, but seeing inequality of poverty in eastern Indonesia which is still high compared to the national average. will be a chore that must be completed by the government immediately. On the other hand there are still many challenges such as the independent Papuan separatist movement which is still provoking the population in Papua, the intolerant movement of the radicals, then the low quality of education, low purchasing power of the people, cases of corruption which are also high, the use 
of natural resources to enrich themselves and a host of other homeworks that are still largely unresolved.

If you look at the data of the Badan Pusat Statistik (BPS) in 2018 on the index of human development in Indonesia the trend has experienced a good increase in 2018 at a position of $71.39 \%$, with a trend in the period of almost a decade from 2010-2018 experiencing an average national growth of $0.88 \%$, the highest position occupied by DKI Jakarta Province with its human development index figure being at $80.47 \%$ with a growth of $0.51 \%$ from $2017-2018$ and the lowest being occupied by Papua Province at position 60, 64\% with a growth of $1.64 \%$ from 2017 2018.

When referring to BPS data, there are still significant gaps in Indonesia's human development so far, people who are close to the center of government tend to have a better quality of life compared to people who are far from the center of government. This clearly proves that the presence of the State is needed in every inch of Indonesia's homeland. In realizing the $5^{\text {th }}$ precepts of the Pancasila "Social Justice for All Indonesian People", it is appropriate for the State to have development priorities for the eastern part of Indonesia to be on par with other parts of Indonesia.

\section{Conclusion}

Social justice in the Unitary State of the Republic of Indonesia, which has a foundation of the Pancasila ideology, provides a space for the concept of justice as a whole and comprehensively, covering all sectors of national and state life which must be carried out by all citizens of the nation. In order to create comprehensive justice, the State must attend and have a scale of development priorities so that eastern Indonesia can have a quality of life that is equivalent to the population of Indonesia in the west.

\section{References}

https://kominfo.go.id/content/detail/3298/sekilas-palaparing/0/palapa_ring (ilmupemerintahannkri.blogspot.com) 
Safaat, Muchammad Ali, Pemikiran Keadilan (Plato, Aristoteles, dan John Rawls), sebagaimana dikutip darihttp://www.bartleby.com/61/83/PO398300.html, accessed date 26 oktober 2019 Wahid, Abdurrahman, Konsep-Konsep Keadilan, http://www.gusdur.net/id/gagasan-gusdur/konsep-keadilan. accessed date 26 Oktober 2019www.klikpengertian.com/2016/01/konsep-nkri-menurut-uud-tahun-1945.html, accessed date 26 Oktober 2019

(www.dharmasetyawan.com)

(www.scribd.com) 